\title{
Reforming the content of general secondary education in independent Ukraine (1991-2017): historiography and sources of the study
}

\author{
L. D. Berezivska \\ V.O. Sukhomlynskyi State Scientific and Pedagogical Library of Ukraine, Kyiv, Ukraine \\ Corresponding author. E-mail: lberezivska@ukr.net_ORCID: 0000-0002-5068-5234
}

Paper received 28.01.21; Accepted for publication 16.02.21.

https://doi.org/10.31174/SEND-PP2021-245IX96-02

\begin{abstract}
The article characterizes the historiography of the problem, which made it possible to identify the works of scientists who were directly involved in the development of theoretical and methodological foundations of the content of general secondary education in independent Ukraine (1991-2017). The author has systematized and typologized the source complex: official documents (laws, doctrines, standards, concepts), analytical materials (national report, etc.), initiative authorial (individual, collective) concepts of the content of educational branches of general secondary education.
\end{abstract}

Keywords: reforming the content of general secondary education, pedagogical historiography, pedagogical source studies, laws, doctrines, standards, concepts, independent Ukraine.

Introduction. With the proclamation of Ukraine's independence in the new socio-political, socio-economic and cultural realities, the priority task of the state policy has become the renewal of the content as one of the most important components of general secondary education. Its conceptual foundations have become the subject of study at the state, scientific, educational-practical and social levels. The published works of scientists, teachers, education chiefs are on the pages of periodicals, where they covered theoretical and methodological approaches to reforming the content in accordance with the new requirements of the Ukrainian school. Now the historiographic understanding of this process in independent Ukraine is gaining relevance.

A brief overview of publications on the topic. Historiographic search has shown that various aspects of the problem of reforming the content of general secondary education in independent Ukraine in the historical and pedagogical aspect, to a greater or lesser extent, were considered by scientists during the outlined period: V. Kremen, 1999, 2000, 2003, 2015; O. Savchenko, 2002; N. Bibik, 2007; M. Vachevskiy, G. Kilyova, 2010; V. Kasyanov, 2015; V. Kamyshyn, B. PiontkovskyiVykhvaten, N. Fedorova, 2015 and others. [11; 12; 13; 14; $15 ; 6 ; 10 ; 9 ; 8]$. We raise this issue in our publications (L. Berezivska, 2011; 2018; 2019; 2020) $[1 ; 2 ; 3 ; 4 ; 5]$. At the same time, we state the absence of historiographical works devoted to the problem of reforming the content of general secondary education in Ukraine during 1991-2017.

The purpose of the article is to characterize historiography and sources of the study on the outlined topic to identify the issues that deserve further study.

Materials and methods. To achieve the goal, we have analyzed modern periodicals, analytical materials, on the pages of which were presented regulatory documents and articles on reforming the content of school education in Ukraine during the period under study. At the same time, various methods were used, in particular, historiographic analysis and historiographic synthesis, source study, thematic, chronological, which enabled the reconstruction of the reflection of the process of reforming the content of general secondary education in independent Ukraine in the scientific works (1991-2017).

Results and Discussion. The historiographic knowledge of the problem made it possible to identify a number of works that consider the process of reforming the content of general secondary education in the era of independence (1991-2017). First of all, these are the works of scientists who were directly involved in the development of the theoretical and methodological foundations of the content of school education. It is noteworthy that these research surveys are also the sources of the study.

The publications by academician V. Kremen are of historiographic value. In the article "The content of education and a didactic strategy" (1999), the scientist reveals the cultural and historical preconditions for building the content of education and the principles of didactic design of educational content in the context of the development of the state independence. Of importance is the idea that in the history of pedagogy, the problem "was solved in different ways: from the idea of general simplification to differentiated acquisition of educational material within the framework of certain educational programs. Those scientific approaches which are based on the principles of variability of the content of education on the basis of its fundamentality or practicality deserve attention too" $[12$, p. 51]. Changes in the content of general secondary education that took place during the first decade since gaining independence (on the importance of the State Standard of Primary Secondary Education, the Concept of 12-Year General Secondary Education, the Laws "On Education", "On General Secondary Education") were analyzed by the minister of education and science of Ukraine V. Kremen in the article "Fundamental provisions of the state educational policy" (2000) [11]. In his opinion, the new content of education "should provide conditions for the intellectual, social, moral and physical development and self-development of pupils, the upbringing of a citizen-patriot, and thereby lay the foundation for the establishment of a democratic society" [11, $p$. 7].

Researchers M. Vachevskyi, G. Kilyova substantiate the main directions of strategic changes in the development and implementation of the content of general secondary education. In particular, they note that "improving the content of education is traditionally a topical and multifaceted problem. Objectively, its solution cannot be completed for a long period of time, since the state and society are constantly changing the requirements for the quality of education, new ideas appear in pedagogical science, the results of content approbation in mass pedagogical practice are 
comprehended" [10, p.18]. M. Zerkal analyzes the regulatory framework, peculiarities of the content of curricula, textbooks for secondary and specialized educational institutions of ethnic minorities in an independent state during 1990-2000. [7]. V. Kamyshyn, N. Fedorova, B. Piontkovskyi-Vyhvaten characterize the changes in the content of secondary education aimed at the development of gifted students (regulatory framework, academic subjects, educational institutions, conceptual ideas for reforming the content of education, basic and variable components, lyceums and gymnasiums as new types of educational institutions, etc.) in Ukraine in the $90 \mathrm{~s}$ of the $\mathrm{XX}^{\text {th }}$ century [8]. V. Kasyanov, on the basis of experts' conclusions, cites problems related to the content of school education (redundancy of the "academic" component and overload of school curricula and textbooks, lack of plans for a systemic reform of the content of secondary education) [9, p. 29].

The article by academician O. Savchenko "Stages of reforming the content of school education in Ukraine during the years of independence" (2002) deserves special attention, describing the most important ideological and pedagogical prerequisites that determined the selection of the content of general secondary education in Soviet times, four periods of reforming the content of school education in Ukraine during 1991-2002: 1991-1995 - depoliticizing the content of education and entering into a national character; 1996-1999 - work at the state standard of general secondary education; 1998-2000 - rethinking the goals of general secondary education as a social institution and an integral system that makes up lifelong education; 20002002 - creating a draft Basic Curriculum for general and high school [15]. In the source study dimension, the publication covers the history of the creation of certain regulatory documents.

In this direction, the article by academician N. Bibik "Problems of scientific support for the modernization of general secondary education (based on the report at a scientific session dedicated to the 15 th anniversary of the NAES of Ukraine)" (2007) stands out. The scientist reveals the significance of the State standard of general secondary education, the Concept of profile education for the development of new content, notes the leading role of scientists of the Institute of Pedagogy of the Academy of Educational Sciences of Ukraine in the development of these documents [6].

The collective work "On the content of general secondary education: scientific and analytical report" (2015) [14] is fundamental in the context of the problem under study. As it states, it was the National Academy of Educational Sciences of Ukraine, upon the initiative of its president, academician V. Kremen, that began a public project for the preparation of a scientific and analytical report on the problems of improving the content of education [14, p. 5]. It is noteworthy that scientists from the Institute of Pedagogy, G.S. Kostyuk Institute of Psychology, the Institute of Problems of Educational of the Academy of Educational Sciences of Ukraine, A.M. Marzeyev Institute of Hygiene and Medical Ecology of the Academy of Medical Sciences of Ukraine joined the development of this document. The team of authors (N. Bibik, G. Vaskivska, L. Velychko, O. Lyashenko, S. Maksymenko, Yu. Malyovanyi, O. Pometun, V. Redko, A. Savchenko, O. Topuzov, etc.) on the ba- sis of methodological documentation (state standards, curricula and programs) and textbooks, analysed the content of primary, basic and complete general secondary education in general and in educational sectors in particular. It is important that the report reveals the history of the creation of basic documents that ensured the reform of the content of general secondary education.

The scientific publication "National Report on the State and Prospects for the Development of Education in Ukraine" edited by academician V. Kremen (2016), is of importantance among others. This collective publication highlights the features of the state policy in the field of education, in particular, it reflects the formation and development of the content of general secondary education in Ukraine during 1991-2016 [13].

The historiographic search showed the absence in Ukrainian historiography of systematic work both on reforming the content of general secondary education in Ukraine of the outlined period, and on the historiography of this problem. At the same time, its historiographic knowledge made it possible to identify and typologize the accumulated sources.

Based on the source analysis of periodicals and Internet resources, we have systematized the source base of the problem of reforming the content of general secondary education in independent Ukraine. It should be noted that an important component of the source complex are official documents (laws, doctrines, strategies, concepts), which outline the conceptual foundations of the content of general secondary education:: Concept of General Secondary School of Ukraine (1991), State National Program "Osvita" ("Ukraine of the XXI Century") (1993), Concept of State Standard of General Secondary Education in Ukraine (1996), Draft Law of Ukraine "On General Secondary Education" (1997), Law of Ukraine "On General Secondary Education" (1999), Concept of General Secondary Education (12-year school) (2001), National Doctrine of Education Development (2002), Concept of specialized education in high school (2003), Concept of developing a new version of the State Standard of Primary General Education (2010), National Strategy for Education Development in Ukraine until 2021 (2013), Concept of specialized education in high school (2013), Concept of secondary school in Ukraine (2015), Concept of implementation of state policy in the field of general education reform secondary education "New Ukrainian School" for the period up to 2029 (2016), the Law of Ukraine "On Education" (2017).

In the source complex, a significant place is occupied by analytical documents the White Book of National Education of Ukraine (2010) National Report on the State and Prospects of Education Development in Ukraine (2011), National Report on the State and Prospects of Education Development in Ukraine (2016).

A separate group of sources is made up of state standards of general secondary education as a tool for preserving a single educational space of Ukraine: primary (State standard for primary general education, 2001; State standard for primary general education for children in need of correction of physical and (or) mental development, 2004; State standard for primary general education, 2006; State standard for primary general education, 2011) and general basic and complete secondary education (State standard for basic and complete secondary education, 2004; State 
standard for basic and complete general secondary education, 2011).

The authorial initiative (individual. collective) concepts became a new genre of modeling the content of educational areas of general secondary education in the times of independence. Among them, there are those in which the content of general secondary education is considered as a component of lifelong education (Concept of labor training of pupils of the national school of Ukraine, 1991; Concept of literary education, 1994; Concept of informatization, 1994; Concept of continuous historical education in Ukraine, 1995; Concept of continuous biological education in Ukraine, 1995; Concept of continuous basic chemical education in Ukraine, 1995; Concept of language education in Ukraine 2011, etc.).

A separate group includes the concepts of the content of educational areas of general secondary education, namely: Concept of literary education. The unity of the national humanitarian education in the multiethnic conditions of Ukraine, 1992, 1993; Concept "Ukrainian Studies", 1994; Concept of school mathematical education, 1996; Concept of studying languages of national minorities in general education schools of Ukraine, 1997; Concept of teaching foreign languages at a 12-year general secondary education school, 2004; Concept of school biological education, 2001; Concept of school chemistry education, 2001; Concept of physical education at a 12-year general education school, 2001; Concept of teaching informatics at general education institutions, 2013; Concept of teaching geography of Ukraine at basic and high school, 2017, etc. These works cover one or all levels of general secondary education.

The named documents which are different in volume, structure and purpose, reflect changes in the content of general secondary education in general and educational areas in particular during the development of Ukrainian statehood. They are the result of the creative work of a cohort of Ukrainian scientists and educators.

Conclusions. Thus, historical and pedagogical historiography does not contain a holistic, comprehensive and systematic work on reforming the content of general secondary education in independent Ukraine (1991-2017). The first attempt at historiographic cognition of the problem made it possible to identify the research of the creators of the national education system (N. Bibik, V. Kremen, O. Lyashenko, O. Savchenko, etc.) that presented evaluative judgments about the dynamic process of developing the theoretical foundations of the content of general secondary education, normative bases in different years of the researched period. At the same time, the fulfilled source study search made it possible to systematize and typologize the initial complex of the problem: official documents (laws, doctrines, standards, concepts), analytical materials (national report, etc.), initiative authorial (individual, collective) concepts of the content of general secondary education. Among them, two groups can be distinguished: the first one includes concepts presenting the content of general secondary education as a component of lifelong education; the second includes concepts reflecting the content for all levels of general secondary education. These documents require further study in the historical and source study context which will be discussed in our publications.

\section{ЛІТЕРАТУРА}

1. Березівська, Л. Д. Журнал «Рідна школа» як джерело історії реформування загальної середньої освіти в Україні: концепції і проекти (1991-2002) // Педагогічні науки : зб. наук. пр. / Херсон. держ. ун-т. Херсон, 2018. № 81. С. 13 20.

2. Березівська, Л. Д. Реформування шкільної освіти в Україні в умовах державотворення (початок $90-\mathbf{x}$ років XX ст.) // Молодь і ринок. 2011. № 6. C. 17-21.

3. Berezivska L. D. Periodization of the reform of general secondary education in the independent Ukraine (1991-2017) // Science and Education a New Dimension. Pedagogy and Psychology. Budapest, 2020. Vol. VIII (92), Iss. 228. P. 15-17. URL https://seanewdim.com/uploads/3/4/5/1/34511564/ped_psy_viii_228_92.pdf.

4. Berezivska Larisa Secondary education reform in the independent Ukraine (1991-2017): concepts, programmes, doctrines and strategies / Larisa Berezivska // Science and Education a New Dimension. Pedagogy and Psychology. Budapest, 2019. Vol. 7 (76), Iss. 187. P. 20-22. URL: http://seanewdim.com uploads/3/4/5/1/34511564/ped_psy_vii_187_76.pdf

5. Berezivska L. D. Secondary education reform in the independent Ukraine: national lawmaking (1991-2017) // Ricerche di Pedagogia e Didattica. Journal of Theories and Research in Education. 2020. [S. 1.], Vol. 15, № 1. P. 53-69. URL: https://rpd.unibo.it/article/view/10501.

DOI: https://doi.org/10.6092/issn.1970-2221/10501.

6. Бібік Н. Проблеми наукового забезпечення модернізації загальної середньої освіти (за матеріалами доповіді на науковій сесії, присвяченій 15-річчю АПН України) // Післядиплом. освіта в Україні. 2007. № 2. С. 17-20.

7. Зеркаль М. М. Етнічна система освіти України: особливості відродження та функціонування у 1990-2000-ті роки

(на прикладі середніх та спеціальних навчальних закладів) // Чорноморський літопис. 2012. Вип. 6. С. 125-131.

8. Камишин В. В., Федорова Н. Ф., Піонтковський-Вихватень Б. О. Модернізація змісту середньої освіти в Україні у 90$\mathrm{x}$ роках XX століття, спрямована на розвиток обдарованих учнів // Освіта та розвиток обдарованої особистості. 2015. № 11 (42). C. 5-15.

9. Касьянов Г. Освітня система України 1990-2014 : аналіт. огляд / Благодійний фонд «Інститут розвитку освіти». Київ : ТАКСОН, 2015. 52 с.

10. Кільова Г., Вачевський М. Зміст загальної середньої освіти, іï реформування, становлення і розвиток // Молодь і ринок. 2010. № 11. С. 18.

11. Кремень В. Г. Засадничі положення державної освітянської політики // Директор школи, ліцею гімназії. 2000. № 1. C. 6-10.

12. Кремень В. Г. Зміст освіти й дидактична стратегія // Освіта і наука України: шляхи модернізації (Факти, роздуми перспективи). Київ : Грамота, 2003. С. 47-58.

13. Національна доповідь про стан і перспективи розвитку освіти в Україні / Нац. акад. пед. наук України ; за заг. ред. В. Г. Кременя. Київ : Пед. думка, 2016. 448 с. (До 25-річчя незалежності України).

14. Про зміст загальної середньої освіти : наук.-аналіт. доп. / за заг. ред. В. Г. Кременя. Київ : НАПН України, 2015.118c.

15. Савченко О. Я. Етапи реформування змісту шкільної освіти в Україні за роки незалежності // Розвиток педагогічної і психологічної наук в Україні, 1992-2002 pp. : зб. наук. праць до 10-річчя АПН України / Академія пед. наук. Харків : ОВС, 2002. Ч. 1.С. 210-227. 


\section{REFERENCES}

1. Berezivska, L.D. "Ridna Shkola" Journal as a Source for the History of Reforming General Secondary Education in Ukraine: Concepts and Projects (1991-2002) // Pedagogichni Nauky: Collection of scientific works. Kherson, 2018. № 81. P. 13-20. http://ps.stateuniversity.ks.ua /file/issue_81/part_1/3.pdf.

2. Berezivska, L.D. Reforming school education in Ukraine in the conditions of state formation (early 90 s of the XX century) //Molod i rynok. 2011, Issue 6. p. 17-21.

6. Bibik N. M. Problems of scientific support for the modernization of general secondary education (based on the materials of the report at a scientific session dedicated to the 15th anniversary of the Academy of Eduactional Sciences of Ukraine // Pisliadyplomna osvita v Ukraini. 2007. № 2. C. 17-20.

7. Zerkal M. Ethnic education system of Ukraine: the revival of the features and operation in 1990-2000s (for example, secondary and special schools) // Chornomorskyi litopys. 2012. Iss. 6 . P. 125-131.

8. Kamyshin V. V., Fedorova N. F., Piontkovskyy-Vykhvaten B. O.The modernization of secondary school Education in Ukraine during the 1990 saimed the development of gifted students // Education and development of gifted personality. 2015. № 11 (42). P. 5-15.
9. Kasyanov, G. Educational system of Ukraine 1990-2014: analytical review. Kyiv: TAKSON, 2015. 52 p.

10. Kilova H., Vachevskyi M. The content of general secondary education, its reform, formation and development // Molod i rynok 2010. № 11. P. 18.

11. Kremen V. G. Basic provisions of the state educational policy // Dyrektor shkoly, litseiu, himnazii. 2000. № 1. P. 6-10.

12. Kremen V. G. The content of education and didactic strategy // Education and Science of Ukraine: Ways of Modernization (Facts, Reflections, Prospects). Kyiv : Gramota, 2003. P. 4758.

13. National report on the state and prospects of the development of education in Ukraine (To the 25th anniversary of Ukraine's independence) / ed. by V. G. Kremen. Kyiv : Pedagogichna Dumka. 2016. P. 448.

14. On the content of general secondary education: scientific and analytical report / ed. by V. G. Kremen. Kyiv : NAPN Ukrainy, 2015. $118 \mathrm{p}$.

15. Savchenko, O. Ya. Stages of reforming the content of school education in Ukraine during the years of independence // Development of pedagogical and psychological sciences in Ukraine, 1992-2002: collection of scientific works to the 10th anniversary of the NAES of Ukraine / Academy of the Educational Sciences. Kharkiv: OVS, 2002. Part 1.P. 210-227. 